
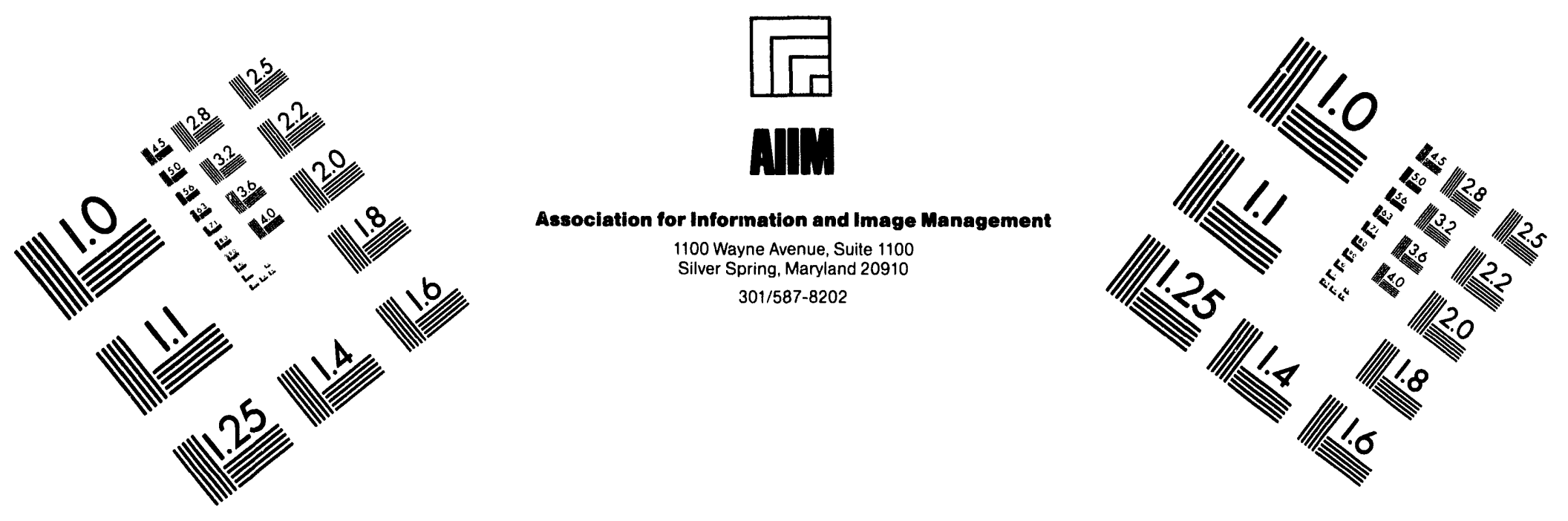

\title{
Centimeter
}

| Inches
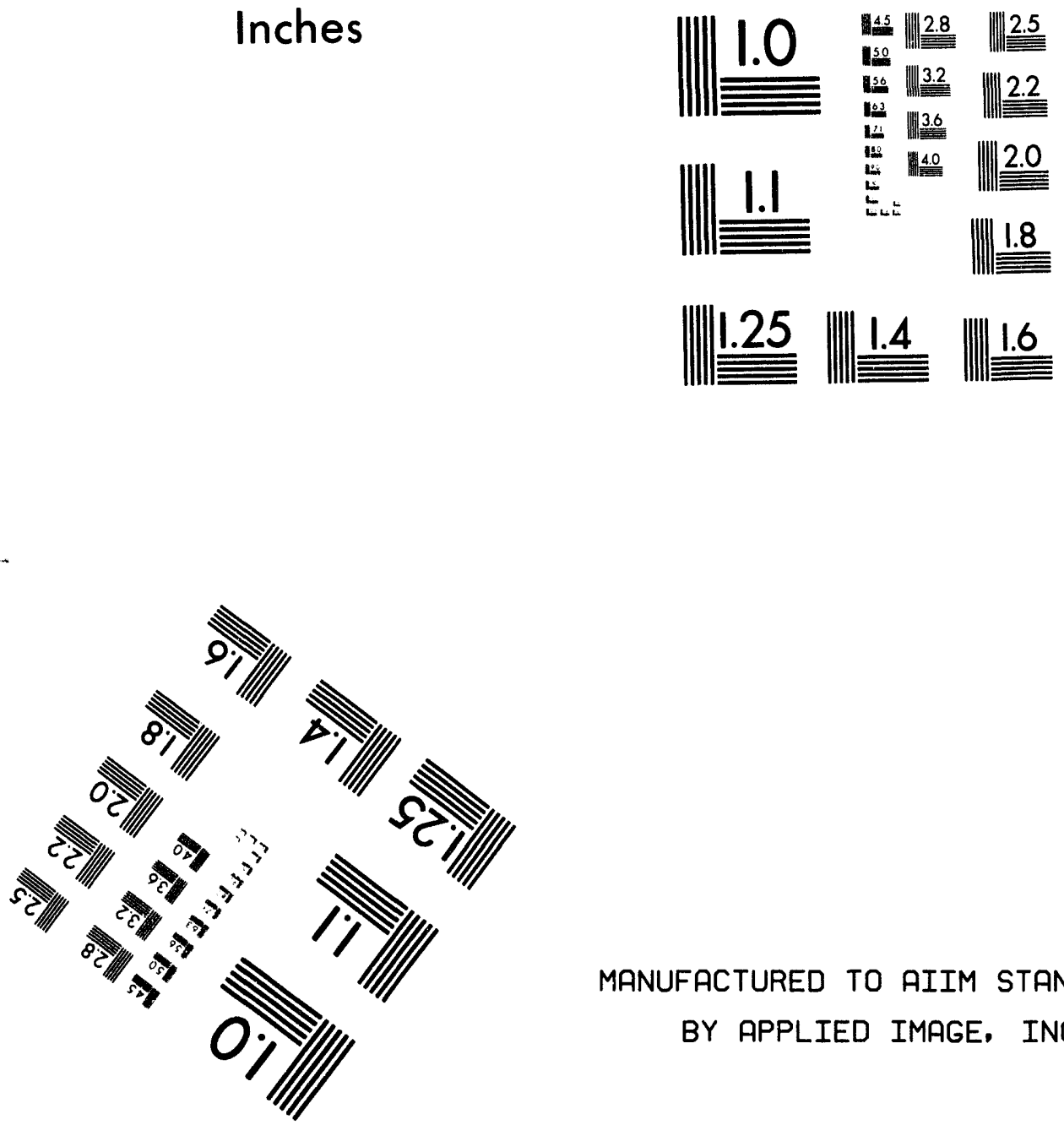

MANUFACTURED TO AIIM STANDARDS

BY APPLIED IMAGE, INC.

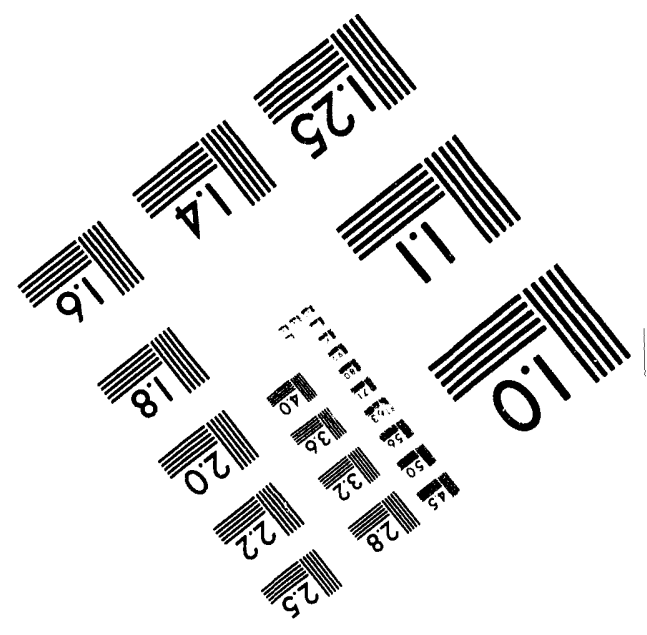



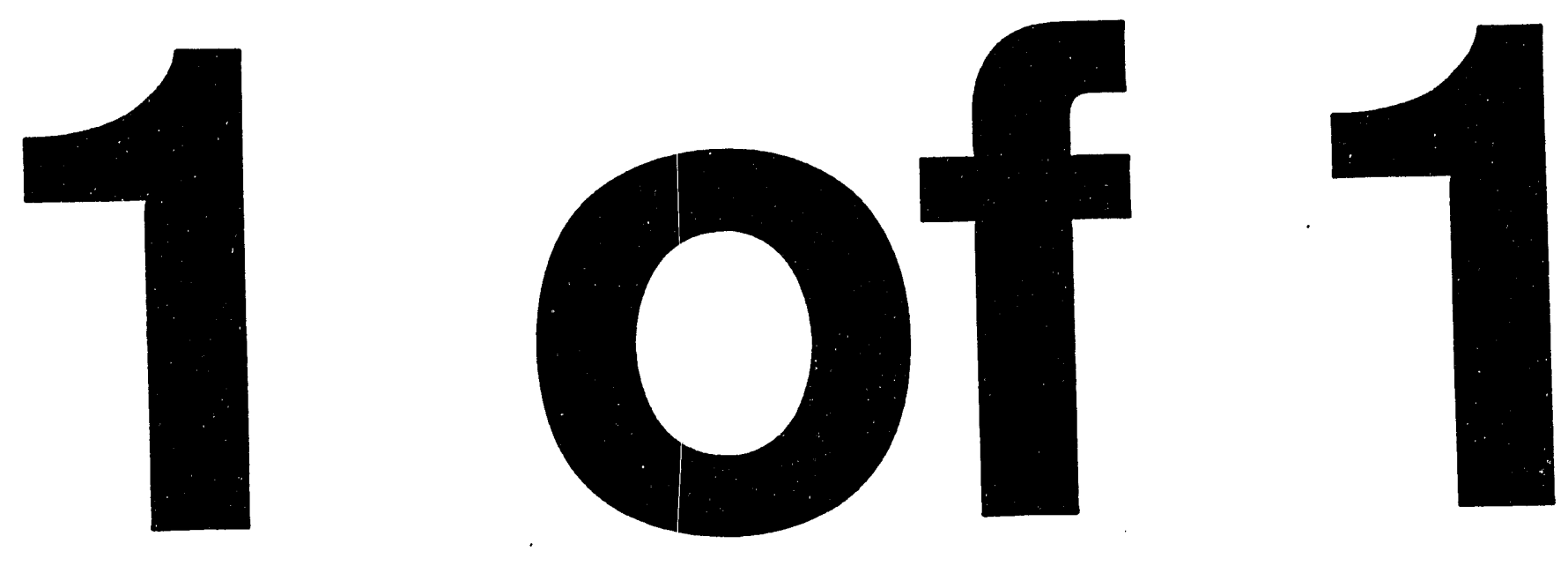


\section{Strategic Petroleum Reserve}

\section{Quarterly Report}

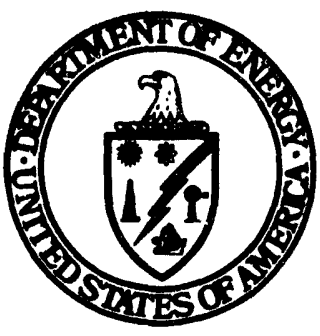

May 15, 1994

\section{U.S. Department of Energy}

Assistant Secretary for Fossil Energy Office of Strategic Petroleum Reserve

Washington, DC 20585 


\section{TABLE OF CONTENTS}

EXECUTIVE SUMMARY

I. STORAGE FACILITIES $\ldots \ldots \ldots \ldots \ldots \ldots \ldots \ldots \ldots$

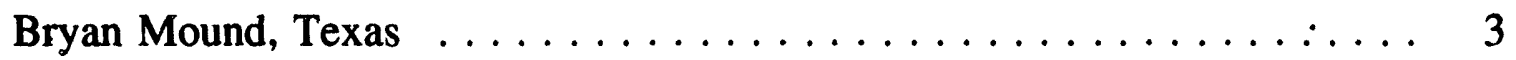

Big Hill,Texas . ..................... 3

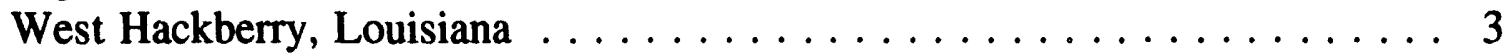

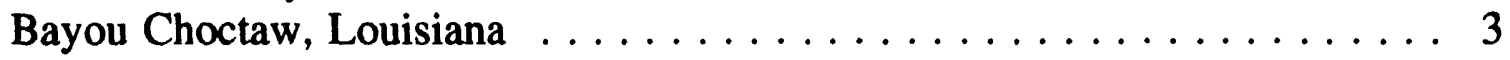

Weeks Island, Louisiana $\ldots \ldots \ldots \ldots \ldots \ldots \ldots \ldots \ldots \ldots \ldots$

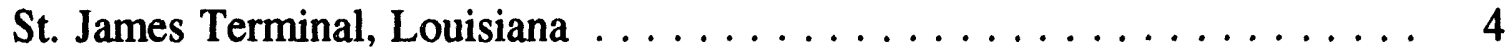

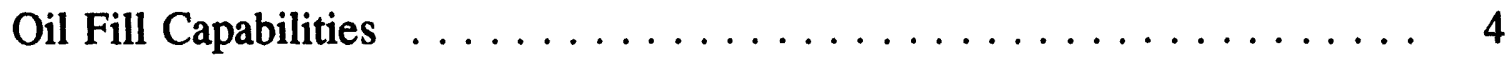

Drawdown/Distribution Capabilities $\ldots \ldots \ldots \ldots \ldots \ldots \ldots \ldots$

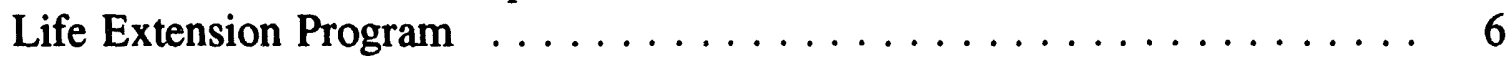

Expansion Planning $\ldots \ldots \ldots \ldots \ldots \ldots \ldots \ldots \ldots \ldots \ldots \ldots \ldots \ldots \ldots$

II. OIL ACQUISITION AND FILL $\ldots \ldots \ldots \ldots \ldots \ldots \ldots \ldots$

III. BUDGET AND COST $\ldots \ldots \ldots \ldots \ldots \ldots \ldots \ldots \ldots$

Funds Available For Obligation . . . . . . . . . . . . . . 9

Oil Acquisition and Transportation (SPR Petroleum Account) . . . . . . 9

Financial Transactions, Second Quarter of Fiscal Year $1994 \ldots . . \ldots .99$

Planned Use of SPR Petroleum Account Funds . . . . . . . . . . . . 9

Storage Facilities Development and Operations and Management (Strategic

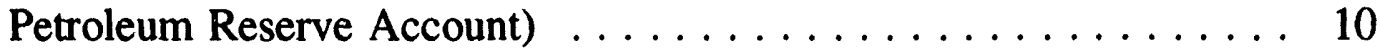

Financial Transactions, Second Quarter of Fiscal Year 1994 . . . . . . . 10

IV. SPECIAL TOPICS $\ldots \ldots \ldots \ldots \ldots \ldots \ldots \ldots \ldots \ldots \ldots$

Impacts on Drawdown Rate Due to Gas Build-up and Elevated Temperature 11

Commercial Use of Strategic Petroleum Reserve Distribution Facilities . . 12

Tiger Team Assessment $\ldots \ldots \ldots \ldots \ldots \ldots \ldots \ldots \ldots \ldots \ldots$ 


\section{LIST OF TABLES}

TABLE I-1

Page

Strategic Petroleum Reserve Storage Capacity . . . . . . . . . . . . . . . 5

TABLE II-1

Strategic Petroleum Reserve Oil Inventory and Delivery Statistics . . . . . . . . 8 


\section{STRATEGIC PETROLEUM RESERVE QUARTERLY REPORT}

\section{EXECUTIVE SUMMARY}

The Strategic Petroleum Reserve serves as one of our most important investments in reducing the Nation's vulnerability to oil supply disruptions. Its existence provides an effective response mechanism should a disruption occur and a formidable deterrent to the use of oil as a political instrument.

The Strategic Petroleum Reserve was created pursuant to the Energy Policy and Conservation Act of December 22, 1975, (Public Law 94163) as amended, to reduce the impact of disruptions in supplies of petroleum products and to carry out obligations of the United States under the Agreement on an International Energy Program. Section 165(a) of the Act requires the submission of Annual Reports and Section 165(b)(1) requires the submission of Quarterly Reports. This Quarterly Report highlights activities undertaken during the first quarter of calendar year 1994, including:

- $\quad$ inventory of petroleum products stored in the Reserve, under contract and in transit at the end of the calendar quarter;

- fill rate for the current quarter and projected fill rate for the next calendar quarter;
- $\quad$ average price of the petroleum products acquired during the calendar quarter;

- current and projected storage capacity;

- analysis of existing or anticipated problems with the acquisition and storage of petroleum products, and future expansion of storage capacity;

- funds obligated by the Secretary from the SPR Petroleum Account and the Strategic Petroleum Reserve Account during the prior calendar quarter and in total; and

- major environmental actions completed, in progress, or anticipated.

Progress continues in quantifying and planning corrective action on two problems that, although readily correctable, have temporarily reduced the availability of some of the oil inventory for drawdown. These problems are a higher-than-normal gas content in some of the crude oil, apparently from years of intrusion of methane from the enclosing domal salt, and an elevated temperature of some of the crude oil due to natural geothermal 
heating. These phenomena have resulted in an increase in the vapor pressure of the oil which could result in emissions that exceed environmental and safe operating limits during a drawdown.

Investigations are nearly complete in determining the precise extent to which gas intrusion and geothermal heating are impacting the availability of oil for drawdown. A temporary unavailability for drawdown of approximately 60 million barrels of the Strategic Petroleum Reserve's inventory and a temporary reduction of the Strategic Petroleum Reserve's drawdown rate are the current estimated impacts of the hot and gassy oil conditions. Engineering design for heat exchangers to cool the oil during drawdown operations is completed with installation scheduled for completion in March 1995. The proposed cooling of the oil meets the requirements for a categorical exclusion determination (SPR-A03) and, therefore, is excluded from further National Environmental Policy Act review and documentation. An Environmental Assessment on stabilizing crude oil impacted by the presence of excessive gas is being prepared by the Department of Energy. Degasification of the affected crude oil is scheduled to begin in February 1995 and to be completed by the end of 1997. 


\section{STORAGE FACILITIES}

The Department of Energy owns and operates five storage facilities on the Gulf Coasts of Texas and Louisiana for the underground storage of crude oil in salt domes: Bryan Mound and Big Hill in Texas and West Hackberry, Bayou Choctaw, and Weeks Island in Louisiana have been developed to store 750 million barrels of oil. The Department also constructed and operates a marine and pipeline distribution terminal on the Mississippi River in St. James, Louisiana. The following is a summary of the current status of the facilities, their respective oil fill and drawdown/distribution capabilities, the facilities Life Extension Program, and expansion planning activities.

\section{Bryan Mound, TeXas}

The Bryan Mound Storage facility, near Freeport, Texas, is available for fill and/or drawdown operations. The site has a storage capacity of 226 million barrels and an inventory of 217 million barrels.

A construction contract for replacement of the deteriorated brine pipeline at the Bryan Mound facility was awarded to Maitland Brothers on September 15, 1993, and installation of the pipeline is scheduled for completion in September 1994. The existing condition of the brine pipeline does not impact drawdown capability.

\section{BIG HILl, TEXAS}

The Big Hill Storage facility near Winnie, Texas, is available for fill and drawdown operations at this time. The site has a storage capacity of 160 million barrels and an inventory of 41 million barrels.

\section{WEST HACKBERRY, LOUISIANA}

The West Hackberry Storage facility in Cameron Parish, Louisiana, is available for fill and drawdown operations. The site has a storage capacity of 219 million barrels and an inventory of 205 million barrels.

Because of deterioration, the brine disposal pipeline was taken out of service in 1991 and brine disposal is being accomplished using existing brine disposal wells. A program to recomplete some of the existing disposal wells to accommodate a rate of 150,000 barrels per day by utilizing newer disposal technologies was initiated in 1992. Three disposal wells have been recompleted to date, and system testing will be completed later this year.

\section{BAyOU CHOCTAW, Louisiana}

The Bayou Choctaw Storage facility in Iberville Parish, Louisiana, is available for fill and drawdown operations. The site has a storage capacity of 75 million barrels and an inventory of 52 million barrels. 


\section{WEEKS ISLAND, LOUISIANA}

\section{The Weeks Island Storage}

facility in Iberia Parish, Louisiana, is essentially filled to capacity ( 72 million barrels) and is available for drawdown.

In May 1992, a sinkhole was discovered above the salt dome at the Weeks Island site. The sinkhole, which was discovered east of the service shaft, was estimated to be increasing in size by 20 cubic yards per month and was filled with sand during March 1994 for safety reasons and to enable better monitoring of the sink hole's progression. As an initial step in the investigation of this phenomenon, Sandia National Laboratory shot surface seismic transects of the area around the sinkhole; however, these data were inconclusive. Additional seismic and geotechnical investigations are planned during 1994 to understand the loss of material and to determine the integrity of the storage facility.

\section{ST. JAMES TERminal, LOUISIANA}

The St. James Terminal, located 45 miles southeast of Baton Rouge on the Mississippi River, services the storage facilities at Bayou Choctaw and Weeks Island and is available for both fill and drawdown operations.

\section{Oil Fill Capabilities}

As of March 31, 1994, the Reserve had a total storage capacity of 750 million barrels and crude oil inventory of 590 million barrels. The oil fill capabilities for all the storage facilities are shown in Table I-1. 


\begin{tabular}{|l} 
Strategic Petroleum Reserve Storage Capacity \\
(Figures in Millions)
\end{tabular}


DRAWDOWN/Distribution CAPABILITIES

The Strategic Petroleum Reserve's current physical drawdown and distribution capability is 4.3 million barrels per day. However, because of the problems associated with an increase in temperature and gas in the crude oil inventory, the initial drawdown rate is temporarily limited to 2.0 million barrels per day. These temperature and gas phenomena are further discussed elsewhere in this report.

\section{Life Extension Program}

Most of the Strategic Petroleum Reserve's facilities were originally designed for 20-year operational lives and will be reaching the end of their design lives by the year 2000. Many of the mechanical, electrical, and control systems and equipment are experiencing an increasing number of failures and increasing maintenance costs associated with their age. The Life Extension Program, initiated in 1993, will ensure the Reserve's continued mission readiness through the year 2025 by replacing and modernizing worn equipment and systems.

The Mitre Corporation, which provides systems engineering support to the Strategic Petroleum Reserve, is developing a Comprehensive Life Extension Plan for replacing and modernizing the systems and equipment nearing the end of their operational lives. In addition to ensuring the reliability and availability of the Reserve, the Life Extension Program will streamline configurations and standardize equipment, and this will ultimately reduce requirements for spare parts and lower maintenance costs. The Comprehensive Life Extension Plan is scheduled for completion during the next quarter.

\section{Expansion Planning}

The Energy Policy and Conservation Act Amendments of 1990 (Public Law 101-383) required the Department to amend the Strategic Petroleum Reserve Plan to prescribe plans for the expansion of the Reserve to one billion barrels. A Draft Environmental Impact Statement was issued in October 1992 for five sites: Big Hill and Stratton Ridge in Texas, Weeks Island and Cote Blanche in Louisiana, and Richton in Mississippi. Public hearings were held and comments received through July 1993.

At this time, the site selection process and prior plans for issuing a Strategic Petroleum Reserve Plan Amendment in April 1994 have been suspended. The Department plans to address the expansion planning requirement in its proposed legislation to extend the Energy Policy and Conservation Act, which expires September 30, 1994. 


\section{OIL ACQUISITION AND FILL}

During the first quarter of calendar year 1994, the Strategic Petroleum Reserve's crude oil inventory was increased by 3.2 million barrels of sweet crude oil. Virtually all of this oil was purchased on the open market by the Defense Fuel Supply Center, the Reserve's oil purchasing agent. This crude oil, all North Sea Brent from the United Kingdom, was delivered to the Reserve in March under two contracts that were awarded in January and February and provide for a total delivery of 4 million barrels. The remaining contracted amount of approximately 900,000 barrels is being scheduled for delivery during early April 1994.

In addition to the above deliveries, the Reserve also received 111,044 barrels that were the final commercial pipeline shipments of Steven Zone crude oil from Naval Petroleum Reserve Number 1 in California. These pipeline shipments began June 1, 1992, and the total quantity transferred from California to the Strategic Petroleum Reserve by this means amounted to $9,667,951$ barrels.

As of the end of this quarter, there was a remaining fund balance within the Account's fiscal year 1994 outlay cap of approximately $\$ 9.4$ million, which was available for acquiring additional crude oil for the Reserve during fiscal year 1994. The Department plans to expend this amount during the next quarter through an additional purchase on the open market of about 500,000 harrels of oil if oil and tanker prices permit.

The weighted average delivered price for the sweet crude oil acquired for the Reserve during this period was $\$ 15.98$ per barrel, excluding Superfund taxes and costs for administration and terminalling. As of March 31, 1994, the total inventory was $590,256,115$ barrels. Table II-I summarizes the Reserve's crude oil inventory and delivery statistics. 


\begin{tabular}{|c|c|c|}
\hline SI9'Z & 0St'9I & 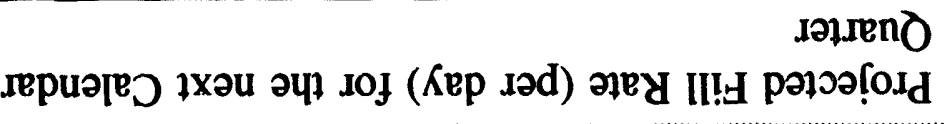 \\
\hline $910^{\circ} t$ & Z9Z`SZ & †66 I reכ \\
\hline $019^{\circ} \mathrm{s}$ & $06 Z^{`} S \mathcal{E}$ & 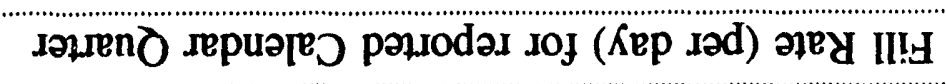 \\
\hline $0 \angle 6^{\circ} 8 S I$ & $000^{\circ} 000^{\circ} \mathrm{I}$ & १!suedL u! I!O jo qunour \\
\hline SI0`E\&8`E6 & SII'9SZ'06S & 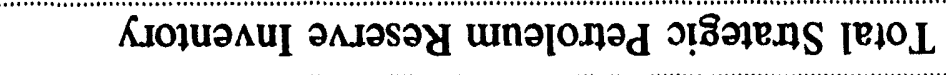 \\
\hline 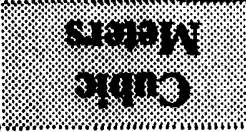 & 89. & \\
\hline \multicolumn{3}{|c|}{ 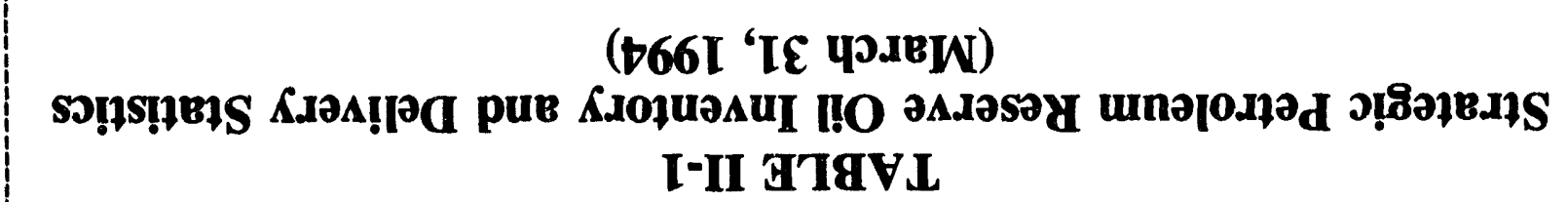 } \\
\hline
\end{tabular}




\section{BUDGET AND COST}

This section provides the financial information required by sectic $n$ 165(b)(1) of the Energy Policy and Conservation Act, as amended.

\section{Funds Avallable For Obligation}

The Department of the Interior and Related Agencies Appropriations Act, 1994 (Public Law 103-138) provided \$206.8 million for operations and management of the Reserve. Including funds carried over from fiscal year 1993, the Strategic Petroleum Reserve Account had \$245.5 million available for obligation in fiscal year 1994. The Appropriations Act also included an outlay cap of $\$ 75.6$ million on funds in the Petroleum Account other than funds appropriated in fiscal year 1993 for oil for national defense purposes. Including balances remaining from the fiscal year 1993 appropriations for national defense oil, total funds available for obligation in the SPR Petroleum Account within the outlay cap during fiscal year 1994 are approximately $\$ 76$ million.

\section{OIL ACQuisition AND TRANSPOR- tation (SPR Petroleum ACCoUnt)}

This activity includes financing for: (1) the Strategic Petroleum Reserve crude oil procurements; (2) associated transportation costs for pipeline and tanker shipments and terminalling; (3) U.S. customs duties and Superfund taxes; and (4) other miscellaneous costs, such as Defense Fuel Supply Center administration costs associated with acquiring and transporting the oil. During a drawdown and sale, this activity funds the Federal cost of drawing down Strategic Petroleum Reserve oil from storage and transporting it to the delivery points where purchasers will take title.

\section{Financial Transactions, Second QUaRTer of Fiscal Year 1994}

During the second quarter of fiscal year 1994, \$72.2 million was obligated from the SPR Petroleum Account. Net disbursements (outlays) from the Account during the same period amounted to approximately $\$ 29.8$ million.

\section{Planned Use of SPR Petroleum ACCOUNT FUNDS}

Although the SPR Petroleum Account contains $\$ 398$ million of obligational authority for Strategic Petroleum Reserve oil acquisition and transportation, the fiscal year 1994 Appropriations Act established an outlay ceiling of $\$ 75.6$ million. The Account also contains \$6 million in obligational authority remaining from the one time appropriation in fiscal year 1993 for the Defense Strategic Petroleum Reserve. 
Storage Facilities DeVelopment AND OPERATIONS AND MANAGEMENT (Strategic Petroleum Reserve ACcounT)

Storage Facilities Development and Operations funding provides for the Strategic Petroleum Reserve facilities program including the construction, operation, and maintenance of the Strategic Petroleum Reserve sites. Management funding provides analyses pertinent to major issues concerning the development and use of the Strategic Petroleum Reserve and for the salaries and expenses necessary to plan and manage the Strategic Petroleum Reserve.

Financial Transactions, Second QUARTER OF FisCal Year 1994

Obligations of $\$ 245.5$ million are available for Storage Facilities Development, Operations, and Management in the fiscal year 1994 , and $\$ 79.3$ million was obligated in the second quarter. Cumulative net obligations for fiscal year 1994 were approximately $\$ 119.8$ million at the end of the second quarter. 


\section{SPECIAL TOPICS}

\section{IMPACTS ON DRAWDOWn RATE DUE TO GAS BUILD-UP AND ELEVATED TEMPERATURE}

The Department continues to progress in quantifying and planning corrective action on two related but distinct problems that, although readily correctable, have temporarily reduced the availability of some oil inventory for drawdown in the near-term. The first of these problems is a higher-thannormal gas content in some of the crude oil apparently from years of intrusion of natural gas from the domal salt, and the second is an elevated temperature of some of the crude oil due to natural geothermal heating. These phenomena have produced an increase in the true vapor pressure of the crude oil that could result in emissions that exceed environmental and safe operating limits during a drawdown. Together, these phenomena have temporarily reduced the amount of crude oil available for drawdown to about 520 million barrels at an initial rate of 2.0 million barrels per day.

To assess the extent to which gas intrusion is impacting the availability of oil for drawdown, pilot plant testing and gas analyses are being conducted on the inventory in each Strategic Petroleum Reserve cavity. Data from these and other tests will be used in designing a plant to degas the crude oil. Conceptual design of an oil degasification plant is underway. Current plans are to degas approximately 200 million barrels of crude oil using two 100,000 barrels-perday plants and blending this degassed oil with the remaining gassy oil at the time of drawdown. All Strategic Petroleum Reserve inventory should be available for a full drawdown after December 1997.

To mitigate the effects of geothermal heating of the crude oil in the near-term, drawdown and distribution scenarios based on pipeline cooling, cavern selection, and flowrate have been developed. Heat exchangers will be constructed initially at Bryan Mound, West Hackberry, and Bayou Choctaw, and ultimately at Big Hill as a long-term means of cooling the crude oil and reducing its vapor pressure to below regulatory limits. A contract for construction of heat exchangers has been awarded, and a solicitation for their installation has been issued. When construction is completed in March 1995, initial sustainable drawdown rate will be increased to about 2.5 million barrels per day.

The proposed cooling of the oil meets the requirements for a categorical exclusion determination (SPR-A03) and, therefore, is excluded from further National Environmental Policy Act review and documentation. An Environmental Assessment on degasifying crude oil impacted by the presence of excessive gases is being prepared by the Department. 
Commercial Use of STrategic Petroleum Reserve Distribition FACILITIES

The Strategic Petroleum Reserve's crude oil distribution system has been based on a strategy of making maximum use of commercial crude oil distribution facilities and minimizing the development and operation of facilities to be used exclusively by the Strategic Petroleum Reserve. However, out of necessity, the Strategic Petroleum Reserve has constructed several crude oil pipelines and one marine terminal to connect its facilities to the commercial infrastructure. During the last year, the Department has received several inquiries from the oil industry to acquire, lease, or use several of the Strategic Petroleum Reserve's pipelines and the Strategic Petroleum Reserve's St. James Terminal to enhance the operation of their own facilities or to avoid having to construct new facilities.

The Department is presently pursuing an initiative for commercial use of its distribution facilities with consideration being given to leasing or outgranting use of one or more of the Strategic Petroleum Reserve's pipelines and the St. James marine terminal while retaining the availability of these facilities to meet national emergency needs. Under Section 159(f)(D) of the Energy Policy and Conservation Act, the Secretary of Energy has statutory authority to "use, lease, maintain, sell or otherwise dispose of storage and related facilities" to the extent necessary and appropriate to implement the Strategic Petroleum Reserve Plan.
Allowing private companies to use Strategic Petroleum Reserve distribution facilities that otherwise would be idle or partially utilized would:

- $\quad$ Reduce the operational cost of the Reserve.

- Establish GovernmentIndustry partnership in meeting commercial needs.

- $\quad$ Provide a source of revenue for the Government.

The Department issued a Press Release and Commerce Business Daily notice on March 16, 1994, requesting industry "Expressions of Interest" in the Strategic Petroleum Reserve's distribution facilities. This was to identify all interested parties and obtain industry's views on possible terms and conditions for a follow-up competitive solicitation. The Department anticipates issuing a competitive solicitation for leasing proposals later this year, with contract awards scheduled for late 1994 or early 1995.

\section{Tiger Team AsSESSMENT}

The Strategic Petroleum Reserve has completed 108 of the 250 corrective actions included in the Corrective Action Plan prepared after the Tiger Team Environmental Safety and Health Assessment in 1992. Of the 218 occupational, safety, and health noncompliance findings, all but one have been completed; the remaining non-compliance finding involves the 
installation of a seven mile potable water pipeline from the City of Winnie, Texas, to the Big Hill site. That pipeline is under contract and scheduled for completion by the end of fiscal year 1994. The Strategic Petroleum Reserve is in the final stages of rebaselining the 1992 Tiger Team Corrective Action Plan. The purpose of rebaselining the remaining 142 findings is to make the Corrective Action Plan current with changes in regulations and new environmental, safety, and health priorities that have arisen since the assessment, and consistent with programs and policies of the new management and operating contractor. The rebaselined plan is expected to be effective in June 1994. 

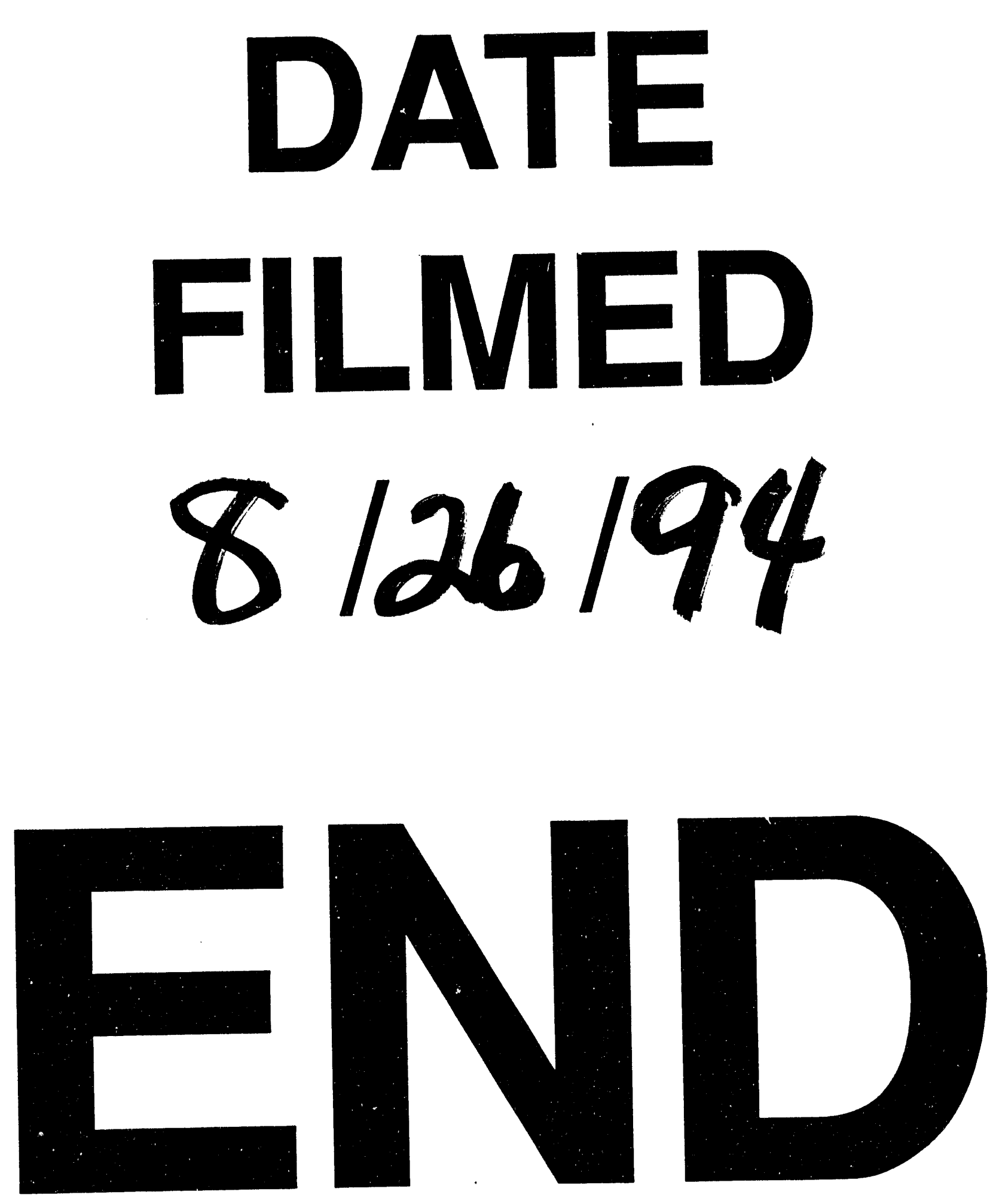


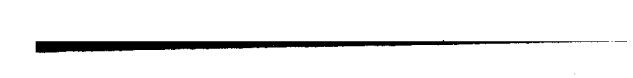

